\title{
POLT PÉTER
}

\section{A büntetőeljárási törvény újításainak várható hatásai}

Finkey Ferenc 1924-es, a törvénysértés fogalmát vizsgáló tanulmányában ${ }^{1}$ hevesen, egyszersmind a tỏle megszokott méltósággal hívta fel a figyelmet arra, hogy van olyan „,súlyosabb természetü kisiklás, elnézés, félreértés vagy helytelen jogi felfogás [...] jogerös itéletben vagy intézkedésben [...], melyet [...] elhallgatni, helyreigazitás nélkül eltürni nem szabad...”.

A koronaügyész világosan felhívta a figyelmet arra a jelenségre, hogy a büntetőeljárás során tapasztalható anomáliákkal öszintén szembe kell nézni, és ha kell, a jogszabályi környezetet kell megváltoztatni ahhoz, hogy megint Finkeyt idézve - ,, a jog uralmának [elve], a törvény szentségének elve, az igazságszolgáltatás magasztos szempont [ja]" érvényesülhessen.

A magyar jogalkalmazás nem elöször nézett szembe saját hibás vagy éppen elavult gyakorlatával. A kormány 2010-ben indította el átfogó büntetőjogi reformját, amely nyomán az új anyagi jogi, majd az új büntetés-végrehajtási kódex megalkotása után, a folyamat befejezéseként a parlament 2017. június 13-án meggyőző többséggel fogadta el a büntetőeljárásról szóló 2017. évi XC. törvényt (a továbbiakban: új Be.).

Az új Be. annyi újdonságot tartalmaz, amellyel igenis számos, reformjellegü (jelentőségü) módosítás épült be a szabályozásba.

Az új Be. újdonságai közül előzetesen azt a mozzanatot kell kiemelni, amely az egész eljárásra és azon belül is minden szereplőre kiterjed. Nevezetesen: az új szemléletet és a szemléletváltozás szükségességét.

Három kérdés vetődik fel az új Be. hatásainak áttekintése kapcsán:

1. miért van szükség új törvényre?;

2. mit jelent ez az „új szemlélet” az eljárás egyes résztvevői számára?; és végül

3. mit várunk az új Be.-től?

\footnotetext{
1 Finkey Ferenc: A törvénysértés fogalma a büntető jogegységi perorvoslatokban. Pallas, Budapest, 1924, 4. o.

2 Uo.
} 


\section{A szabályozás szükségessége}

Az első kérdésre a válasz egyértelmü: Évek óta érezhető volt a jogalkalmazás felől érkező markáns igény, hogy egy áttekinthetőbb szerkezetü, egyszerübb, koherens büntetőeljárási törvényt fogadjon el a parlament. Nem volt elég tehát egy novelláris módosítás, hiszen rendszerszintü és koncepcionális megújításra volt szükség. A büntetőeljárással foglalkozó hivatásrendek, így a bíróság, az ügyészség és az ügyvédi kar is támogatták az új eljárási törvény megalkotását, és abban aktívan közre is müködtek.

Az új büntetőeljárási törvény elsődleges célját már a kodifikáció első fázisában úgy határozták meg, hogy egy olyan kódex megalkotására van szükség, amely megőrzi a magyar eljárásjog hagyományos értékeit, megfelel a modern büntetőeljárásokkal szemben támasztott és az alaptörvényben megfogalmazott követelményeknek, továbbá eleget tesz hazánk nemzetközi egyezményekből fakadó kötelezettségeinek.

Ezeknek a követelményeknek maradéktalanul megfelelve az új Be. a büntetőeljárás új rendszerének alapjait egységes szempontok szerint, az egyes eljárási szakaszok és jogintézmények tekintetében is egymásra épülő elemekre építette fel, felváltva a korábbi Be. széttöredezetté vált, sok esetben következetlen és inkoherens szabályozását.

Új törvény meghozatalát sürgette például az eljárások elhúzódása. Az elmúlt közel tíz évben a regisztrált büncselekmények száma csökkent, míg a rendőrség létszáma emelkedett. Ehhez képest a büntetőeljárások általánosságban is elhúzódnak, 2005-höz viszonyítva egy átlagos nyomozás időtartama mintegy harmadával, míg a bírósági eljárás időtartama megközelítőleg tíz százalékkal emelkedett. Az Emberi Jogok Európai Bírósága Magyarországot több ízben elmarasztalta a büntetőeljárások elhúzódása miatt, különösen felhívnám a figyelmet a Barta és Drajkó kontra Magyarország-ügyre, amelyben a bíróság a kifogás intézményével foglalkozott ${ }^{3}$, továbbá a 2/2017. (II. 10.) $\mathrm{AB}$ határozatra, amely kimondja, hogy ha a bíróság a terhelttel szemben alkalmazott büntetőjogi jogkövetkezményt az eljárás elhúzódása miatt enyhíti, akkor határozatának indokolása rögzítse az eljárás elhúzódásának tényét, valamint azzal összefüggésben a büntetés enyhítését, és az enyhítés mértékét ${ }^{4}$. A költségvetési hatásokon túlmenően nemzetközi presztízsveszteség is, hogy a jelenlegi szabályozásban nincsenek hatékony eszközök a vontatott eljárások elkerülésére.

3 Barta és Drajkó kontra Magyarország-ügy, 35729/12, 2013. december 17.

4 2/2017. (II. 10.) AB határozat 
Emellett olyan társadalmi elvárások is késztették a jogalkotót, hogy a gyorsaságon kívül a büntetőeljárások hatékonyak is legyenek. Azaz a büncselekmények elkövetöit kivétel nélkül, minél kevesebb társadalmi ráfordítás mellett, tisztességes eljárásban vonják felelősségre. A hatékonyság gátja jelenleg számos, a tisztességes eljárás elvének sérelme nélkül lebontható adminisztrációs teher, túlzott formalizmus, ahogy a lehető legkevesebb munkaidőt és költséget igénylö, egyszerü eljárási formák is hiányoznak. Ezen kívül jelenleg nem teljeskörüen adottak a sértettek és a különös bánásmódot igénylő személyek kíméletének és védelmének az egész eljáráson, törvényen átívelő megoldásai.

Harmadsorban a Be. rendszerszintü problémái miatt is új szabály megalkotása vált szükségessé. A Be. 1998-ban elfogadott szövegét 2002-ben az Országgyülés jelentősen átírta, és ezután is két nagyobb, alapvető megoldásokat érintő, fontos irányváltást jelentő módosítás érte, miközben számtalan kisebb-nagyobb változtatás is történt. A Be. ezért mind alapvető megoldásaiban, jogintézményeiben, mind az egyes részletszabályait tekintve jelentős koherenciaproblémákkal küszködött, számos ponton alappal volt kérhető rajta számon a következetlenség. A korábban újdonságként bevezetett jogintézmények nagy része nem váltotta be az eredetileg hozzájuk füzött várakozásokat (például óvadék, távoltartás, tárgyalásról lemondás, kiemelt jelentőségü ügyek külön eljárása), ezek átfogó, egységes szempontok szerinti rendszerezése, adott esetben elhagyása vált szükségessé.

Az előbbiekből is látható hogy a kérdések hatékony megoldása csak rendszerszintü beavatkozással, egy elejétől a végéig új kialakítású és szerkezetü, a büntetőeljárást strukturálisan megújító törvény révén volt elképzelhetö, különös tekintettel arra, hogy a büntetőeljárási szabályozás - a Btk.-tól eltérően jellemzően nem statikus, egymástól független módon szabályozható intézményeket tartalmaz.

Ilyen rendszerszintủ megoldást kívánt a bizonyítás kérdése, a terhelttel történő megállapodás kereteinek kialakítása, a nyomozás struktúrája, a bünüldözési célú titkos információgyüjtés integrálásának kérdése, valamint a jogorvoslati rendszer reformja.

\section{Az eljárás minden szereplőjét érintő szemléletváltozás}

Az új büntetőeljárási törvényről elmondhatjuk, hogy sok tekintetben új alapokra helyezte a büntetóeljárás magyar szabályozását. Nézzük azonban, hogy az említett „új szemlélet” mégis mit jelent az eljárás egyes résztvevői számára! 
Előzetesen megállapítható, hogy a törvény az eljárás minden szereplöje számára tartalmaz újdonságot, és egyúttal minden szereplőtől aktívabb részvételt kíván meg a teljes eljárás folyamán.

A terhelt szerepe például bizonyos tekintetben változik az új törvényben. Ehhez kapcsolódóan az egyezség ${ }^{5}$ intézményét emelném ki.

Jó példa a bírósági tárgyalás racionalizálása érdekében bevezetett perkoncentráció, amely két úton valósulhat meg. Egyrészt az előkészítő ülés első szakaszában szükséges nyilatkoztatni a terheltet, beismeri-e a vád tárgyává tett cselekményt. Ha igen, és egyúttal lemond a tárgyaláshoz való jogáról is, akkor az előkészítő ülésen sor kerülhet az ügydöntő határozat meghozatalára. E folyamatban nagy jelentősége van az ügyész büntetéskiszabási indítványának, amely a hagyományos ügyészi indítvány mellett, a szankció konkrét mértékét is megjelölve kizárólag arra az esetre vonatkozik, ha a terhelt az elökészítő ülésen beismerő nyilatkozatot tesz. Az ügyész ezen indítványánál súlyosabb joghátrányt a bíróság nem alkalmazhat abban az esetben, ha a bíróság a bünösséget beismerő nyilatkozatot az előkészítő ülésen fogadta el. A másik út, amikor elfogadható beismerő nyilatkozat hiányában az előkészítő ülésen kerül sor a tárgyaláson folytatandó bizonyítási eljárás kereteinek kijelölésére. A felek itt tisztázzák, hogy a vád állításai közül melyeket vitatják, és az így meghatározott bizonyítandó tények körében - fö szabályként - itt kötelesek bizonyítási indítványaikat előterjeszteni. A perkoncentráció kapcsán megjegyzem, hogy az előkészítő ülésen a terhelt részvétele kötelező, így távolmaradása abban az esetben is akadálya az eljárás továbbfolytatásának, ha egyébként a tárgyaláson - amelynek előkészítése zajlik - egyébként majd nem kíván jelen lenni'.

A képviselet új szabályaiból a kirendelt védőre vonatkozó nóvumokat említem. A kirendelt védővel kapcsolatos hatályos szabályozás alapján élő joggyakorlat nem bizonyult megfelelőnek a hatékony védelem szempontjából. A büntetöügyekben eljáró hatóságok és az általuk rendszeresen kirendelt védő között kialakult szoros bizalmi kapcsolat gyakorta hátrányosan befolyásolta a védőt jogosultságai gyakorlásában. Ezen anomália kiküszöbölése érdekében az új törvény olyan rendszert valósít meg, amelyben a hatóság kirendelése alapján eljáró védő személyéről nem a hatóság, hanem a kirendelésről értesített területi ügyvédi kamara dönt. Hangsúlyozandó, hogy a törvény szövege szerint a területi, nem pedig az országos ügyvédi kamara feladata az

5 Kónya István: Kúriai szemmel az új Büntetőeljárási törvényröl. Ügyvédek Lapja, 2017/6., 22-23. o. 6 Békés Ádám: A beismerő vallomás és az egyezség lehetőségéről - pro és kontra. Ügyvédek Lapja, 2017/6., 36-38. o. 
eljáró védő kijelölése. Így az előttünk álló hónapokban szükséges annak tisztázása, hogy a törvény elöírásainak megfelelő gyakorlat miként alakítható ki az informatikai lehetöségekre is figyelemmel.

A terhelt és a büntetőügyekben eljáró hatóságok konszenzusára törekvő eljárási forma már a régi Be.-ben is létezett. A tárgyalásról lemondás mint külön eljárás azonban nem tudott ténylegesen meggyökeresedni a joggyakorlatban, a büntetőeljárások befejezési módjaként betöltött szerepe statisztikailag szinte nem is fejezhetö ki. Ugyanakkor egy a tisztességes eljárás követelményeinek is megfelelő konszenzuális eljárás az állam oldalán idö- és költségmegtakarítást, a terhelt oldalán enyhébb szankcionálást, a sértett oldalán biztos jóvátételt, míg a társadalom szempontjából azt idézi elő, hogy a büncselekmény elkövetőjét biztosan felelősségre vonják. Ezért a jogalkotó kísérletet tett a jogintézmény újraszabályozására, ennek következménye a bünösség elismerésére irányuló egyezség. Hangsúlyozandó, hogy a jogintézmény változatlanul alapjaiban eltér az angolszász vádalkutól' ${ }^{7}$ A tényállás és a cselekmény minősítése ugyanis nem lehet a megállapodás tárgya, arról az ügyésznek változatlanul a nyomozás során összegyüjtött bizonyítékok értékelése, egybevetése alapján kell döntenie. A törvény a bünösség elismerésére irányuló egyezség megkötésének folyamatát és lehetséges tartalmi elemeit nem külön eljárásként, hanem az általános eljárás szabályai közt helyezi el, kifejezésre juttatva, hogy egyezségnek helye van bármely ügyben és bármely büncselekmény esetén. A törvény ugyanakkor a terhelti együttmüködéshez kapcsolódóan a terhelt számára nyújtható kedvezmények fokozatosságát szem előtt tartva az egyezség megkötését kizárólag a nyomozás során teszi lehetővé, azaz a vádemelést követően a terhelti együttmüködés már csak az előkészítő ülés során, a bünösség beismerésében nyilvánulhat meg. A törvény az egyezséghez vezető folyamatot is leegyszerüsíti, és megszabadítja minden szükségtelen formalizmustól. Az egyezség megkötését mind a terhelt és a védő, mind az ügyészség kezdeményezheti.

A bíróságot érintő szemléletváltozások közül az előbbiekben említett perkoncentrációra és pergazdaságosságra való törekvés, a bizonyítás, valamint a társasbíráskodás szabályainak változása mellett a jogorvoslati rendszer újdonságait emelném itt ki.

Az ülnökrendszer átalakítása már régi igénye volt a hazai jogalkalmazásnak. Általánosan elfogadott nézet, hogy az ülnökrendszer jelenlegi formájában nem teremt hozzáadott értéket az ítélkezés minőségéhez, ráadásul valódi

7 Lásd még Kovács Tamás: Kell-e nekünk vádalku. In: Vókó György (szerk.): Tanulmányok Polt Péter 60. születésnapja tiszteletére. HVG-ORAC Lap- és Könyvkiadó, Budapest, 2015, 138-154. o. 
eljárási garanciát sem jelent. Az alaptörvény által meghatározott keretek között már a jogalkotás során felvetődött az úgynevezett szakülnöki rendszer kialakításának gondolata. A jelenlegi ülnökrendszer egyik leginkább bírált jellemzője, hogy a többnyire összeszokott tanácsokban eljáró ülnökök nem jelentenek valódi kontrollt, ellensúlyt a hivatásos bírák mellett. A törvényjavaslat végül kompromisszumos megoldásként azon a két területen tartotta fenn az ülnökrendszert, ahol az a leginkább hasonlít a szakülnökök eljárásához. A katonai ülnök a katonai életviszonyokról, míg a fiatalkorúak ügyében eljáró pedagógus és más speciális szaktudással felvértezett és a gyermekvédelemben tapasztalatot szerzett szakember e sajátos korcsoporthoz tartozó elkövetőkről bír olyan speciális ismeretekkel, amelyek életszerübbé tehetik a szakbíró büntetöjogi gondolkodását ${ }^{8}$.

A bírói tanácsok összetételében is észszerüsít az új törvény: a gazdálkodással összefüggő kiemelt büncselekmények körében ${ }^{9}$ elöírja, hogy az e büncselekmények miatt folytatott eljárások során az elsőfokú bíróság három hivatásos bíróból álló tanácsban jár el, és a tanács egy tagja a törvényszék gazdasági, ennek hiányában a törvényszék polgári ügyszakának bírája. Ez a szabályozás egyébként az Európa Tanács Miniszteri Bizottsága ajánlásának figyelembevételével született. ${ }^{10}$

A jogorvoslati rendszer tekintetében egyik legfontosabb elem a korlátozott felülvizsgálat. A törvény - bár a hatályos jogszabályhoz hasonlóan fó szabálynak a teljes revíziót tekinti - bevezeti a korlátozott felülbírálatot elöidéző fellebbezést.

Így fellebbezésnek van helye kizárólag a kiszabott büntetés vagy az alkalmazott intézkedés neme és mértéke vagy tartama ellen; az ítéletnek az egyszerüsített felülvizsgálati eljárás tárgyát képező rendelkezése, a szülői felügyeleti jog megszüntetése iránti indítványt, illetve a polgári jogi igényt érdemben elbíráló rendelkezése; vagy a felmentỏ ítélet, valamint a megszüntető határozat indokolása ellen is. E jogorvoslati eszköz esetében is azonban a törvény - a jogbiztonság érdekében - meglehetősen széles körben feljogosítja a másodfokú bíróságot a törvénysértő ítéleti rendelkezések felülbírálat körébe vonására. Az irányadó tényállás megalapozottságát azonban e kivételes esetekben sem lehet vizsgálat tárgyává tenni.

8 Vida József: A laikus ítélkezésben rejlő garanciák. Ügyvédvilág, 2015/7-8., 26-28. o.

$910 . \S(1)$ bekezdés 3. pont

10 Az Európa Tanács Miniszteri Bizottságának R(87) 18. számú, a büntetőeljárás egyszerüsítéséről szóló ajánlásának III/d/1. 2. és 5 . pontja. 
A jogorvoslati rendszer reformja érinti a megalapozatlanság kérdését is. A hatályon kívül helyezések számának csökkentése érdekében a jogalkotó szélesebb körben tette lehetővé a megalapozatlanság másodfokú eljárásban történő orvoslását. Lehetséges a bünösséghez vezető eltérö tényállás megállapítása is, ami garanciális szempontból sem kifogásolható, hiszen az ellentétes döntéssel szemben a harmadfokú eljárás kezdeményezése lehetőségként fennmarad.

A Be. törvényi szinten határolja el egymástól a teljes és a részleges megalapozatlanság eseteit (592. §). Így az elsőfokú bíróság ítélete teljes egészében megalapozatlan, ha az elsőfokú bíróság nem állapított meg tényállást, vagy a tényállás teljes egészében felderítetlen. Míg részbeni megalapozatlanságról beszélünk, ha az elsőfokú bíróság a tényállást hiányosan állapította meg, a tényállás részben felderítetlen, a megállapított tényállás ellentétes a bíróság által lefolytatott bizonyítást érintő ügyiratok tartalmával, vagy ha az elsőfokú bíróság a megállapított tényekből további tényre helytelenül következtetett. Hatályon kívül helyezésre - megalapozatlanság címén - csak teljes megalapozatlanság esetében kerülhet sor. A részbeni megalapozatlanságot a másodfokú bíróság - legyen az bármilyen mértékü - minden esetben köteles maga kiküszöbölni.

Az ügyész szerepe továbbra is az alaptörvényben meghatározott közvádló, az állam büntetőigényének kizárólagos érvényesítője [29. cikk (1) bek.]. Ebben a minőségében az eljárás minden szakában részt vesz, így a Be. módosításai és újdonságai különösen is érintik az ügyész tevékenységét és az ahhoz szükséges szemléletváltozást. E körben néhány példa alapján világítanék rá egy-egy új elemre.

Az ügyész és természetesen az eljárás többi alanya is hatással lesz az eljárás hatékonyságára. Az új Be. a nyomozó hatóság és az ügyészség kapcsolatára, viszonyrendszerére, a nyomozásban betöltött szerepükre, és az ehhez kapcsolódó felelősségi kérdésekre, továbbá a rendelkezésükre álló eszközrendszerre vonatkozó bizonytalan szabályozást is meg kívánja haladni. Ennek érdekében a gyorsítás eszközeit szerves módon tartalmazó, a párhuzamosság helyett egymásra épülö, több szempontot egyszerre figyelembe vevö, de egységes, kellően rugalmas és a jogalkalmazók döntésében bízó eljárási szabályozás kialakítása a cél. Az alkotmányossági és a hatékonysági szempontokat egyszerre érvényesítő megoldásként a nyomozásnak olyan rendszere épült fel, amelyben a személyre szóló megalapozott gyanú meglététől (közlésétől) függően a nyomozás két szakaszra: felderítésre és vizsgálatra oszlik. A felderítés szakaszának jellemzője, hogy viszonylag kötetlen formá- 
val az adatok - nem elsődlegesen a bizonyíték - gyüjtésére koncentrál. Az e körben rendelkezésre álló nagyobb szakismeret és apparátus miatt ez a szakasz a nyomozó hatóság önállóságával, az ügyészség relációjában a törvényességi felügyeletre jellemzö ügyészi jogosítványokkal jellemezhető. A vizsgálati szakasz pedig tényleges ügyészi kontroll (irányítás) mellett, a konkrét személlyel szembeni vádemelés eldöntéséhez szükséges bizonyítási eszközök beszerzésére irányul a kontradiktórius eljáráshoz hasonló keretek között.

Korábban említettem már a beismerés kérdését, amely fokozottan új ügyészi attitüdöt kíván meg. A beismeréssel kapcsolatos szabályok érvényesülésének feltétele, hogy az ügyész megfelelően állapítsa meg az adott cselekmény tárgyi súlyának megfelelö, a büntetési célok eléréséhez leginkább megfelelő szankció jellegét és mértékét. Ezt ráadásul két eset vonatkozásában kell megállapítani: szükséges tisztázni a terhelt előkészítő ülés során tett beismerése esetén alkalmazandó joghátrányt és a nem beismerő terhelt esetén a bizonyítási eljárást követően indítványozandó szankciót. A cselekmény e kettős „,beárazása” szokatlan, az eddigi gyakorlattól eltérő szemléletet igényel az ügyészektöl. A jogintézmény csak akkor éri el a törvényhozó által kívánt célját, ha valóban a beismerésre ösztönzi az eljárás alá vont elkövetőt. Ezt a szerepét pedig nyilván csak akkor tudja betölteni, ha az előkészítő ülésen kiszabott joghátrány ténylegesen elmarad a tárgyalás után kiszabott büntetéstől. Ezért fontos, hogy a bírósági ítélkezési gyakorlat is - a beismerésnek megfelelő jelentőséget tulajdonítva - kellő különbséget tegyen az előkészítés során, illetve a tárgyalás után kiszabott joghátrányok mértéke között.

A személyi szabadságot korlátozó kényszerintézkedések szabályozását illetően is fontos nóvumról beszélhetünk. A hatályos törvény alapján a kényszerintézkedésekkel összefüggésben kialakult gyakorlatot többször érte az a kritika, hogy túlságosan letartóztatáscentrikus. Ez részben arra volt visszavezethető, hogy a törvény a személyi szabadság korlátozásának eljárásjogi alapjait a letartóztatással összefüggésben rögzítette, és az enyhébb kényszerintézkedések alkalmazását ezeken túlmenő, további speciális körülmények fennállásához kötötte. Az új törvény teljesen új alapokra helyezte a személyi szabadságot korlátozó kényszerintézkedések rendszerét. Ez nemcsak abban mutatkozik meg, hogy egyes kényszerintézkedések megszüntek, másokat pedig átneveztek, hanem tényleges szemléletváltozásra is sor került. Már a törvény 2. §-ának (3) bekezdése rögzíti, hogy a büntetőeljárásban alapvető jog korlátozására csak abban az esetben kerülhet sor, ha az elérni kívánt cél kisebb korlátozással járó más eljárási cselekmény vagy intézkedés útján nem biztosítható. 
Ennek az alapvető rendelkezésnek az érvényre juttatása során a törvény XLV. fejezetében először meghatározzák a személyi szabadságot érintő bírói engedélyes kényszerintézkedések elrendelésére okot szolgáltató célokat, majd az alkalmazható kényszerintézkedések fajtáit erősorrendben: elsőként a távoltartás és a bünügyi felügyelet, majd a letartóztatás és az elözetes kényszergyógykezelés ${ }^{11}$.

Az előkészítő eljárással összefüggésben a bünüldözési célú titkos információgyüjtés megítélése számos vitát váltott ki a közelmúltban. A hatályos szabályozás egyik leggyakrabban bírált, számos konkrét büntetőeljárás kudarcát előidéző területe volt az e tevékenységből származó bizonyítékok felhasználhatóságának kérdése. A megoldási javaslatok közül a titkos információgyüjtés szabályainak büntetőeljárásba történő integrálásának elfogadására került sor. Ez azonban szükségessé tette egy a nyomozást megelőző eljárási szakasz bevezetését. A törvény ezzel a büntetőeljárás megindítását az egyszerủ gyanú szintjét el nem érő információk alapján is lehetővé teszi. Az előkészítő eljárás célja valamely büncselekmény gyanújának megállapítása vagy éppen kizárása.

Az elökészítő eljárás tehát csak akkor folytatható, ha a rendelkezésre álló adatok büncselekmény gyanújának megállapítására nem elegendők, és megalapozottan feltételezhető, hogy az elökészítő eljárás lefolytatása alapján el lehet dönteni, hogy a büncselekmény gyanúja fennáll-e. Mivel ez a tevékenység átfedést mutathat olyan különleges tárgyú felderítö, illetve veszélyelhárító tevékenységekkel, mint a korrupció vagy a terrorizmus elleni küzdelem, a törvény a célszerüségi megfontolásokra is figyelemmel lehetővé teszi, hogy az előkészítő eljárást ne csak a büntetőeljárás lefolytatására hatáskörrel felruházott ügyészség vagy nyomozó hatóság végezhessen, hanem az Rtv. alapján a hatáskörébe tartozó cselekmény miatt a rendőrség belső bủnmegelőzési és bünfelderítési feladatokat ellátó szerve, valamint a terrorizmust elhárító szerve is.

Az új szemléletet vázoló példák között utolsóként, de szerepét nem csökkentve említeném meg a titkosszolgálati eszközök új funkcióját. Számos kiemelt tárgyi súlyú, elsősorban a szervezett bünözéssel összefüggő büntetőeljárás sorsa függ attól, hogy a bíróság a nyomozást megelőzően titkosan (különleges eszközökkel) beszerzett bizonyítékokat elfogadja-e, vagy sem. Az új Be. az eredményes feltárás és bizonyítás érdekében ezért egységesen, a büntetőeljárás rendszerébe illesztve szabályozza a titkosszolgálati eszközökkel beszerzett bizonyítási eszközök büntetőeljárási célú felhasználását, hogy a bizonyítás törvényességéhez később se férhessen kétség.

11 Miskolczi Barna: A kényszerintézkedések új rendszere. Ügyvédvilág, 2016/10., 22-25. o. 


\section{Mit várunk az új törvénytől?}

Ha röviden fogalmazok, akkor mindenekelőtt az eljárás hatékonyságát és gyorsulását, valamint az eljárási szereplők jogainak és kötelességeinek megfelelőbb érvényesülését.

A büntetőeljárás gyorsítására és egyszerüsítésére alkalmas jogintézmények, mint például a bíróság elé állítás, a büntetővégzés meghozatalára irányuló eljárás, a terhelt együttmüködésén alapuló eljárás, a közvetítôi eljárás céljának pontos meghatározásával, feltételeik összehangolásával remélhetőleg elérhető az az alapvető követelmény, hogy ezek az eljárások ne konkuráljanak egymással, hanem az adott ügy körülményeihez igazodva célzottan, a lehetö leghatékonyabban legyenek igénybe vehetők.

A megalapozatlansággal kapcsolatos szabályok egyértelművé válása és a hatályon kívül helyezések rendes jogorvoslattal történő támadásának lehetővé tétele csökkenti az elsőfokú bíróságokra nehezedő, túlbizonyításra ösztönző nyomást. Ez - és az előkészítő ülés perkoncentrációja - feltehetően az elsőfokú bírósági eljárások egyszerüsödését, rövidülését fogja előidézni. Mindamellett a másodfokú bíróságok nagyobb arányban fogják gyakorolni reformatórius jogkörüket, gyakrabban kerül sor a megalapozatlansági hibák akár eltérő tényállás megállapításához vezető orvoslására, így többször születik majd a másodfellebbezés bejelentését megnyitó ellentétes döntés. Mindez valószínűleg a bírósági szintek közötti arányosabb ügyleterheltséghez vezet.

Az azonban, hogy ez mennyiben jár majd ténylegesen a bírák - és így a bíróságok mellett müködő ügyészségek - munkaterhének csökkenésével, egyelőre nem prognosztizálható. A törvény ugyanis számtalan eszközt és lehetôséget kínál a klasszikus bírósági út elkerülésére, de hogy a jogalkalmazó ezzel miként, milyen arányban él, az már a jövő kérdése.

Az büntetőeljárásról szóló új törvény több elemében hoz tehát olyan újdonságot, amellyel az eljárás szereplőinek meg kell birkózniuk. A szembenézés a korábbi gyakorlattal azonban, látva nagy elődünk, Finkey Ferenc karakteres véleményét, nélkülözhetetlen a ma elvárt jogszerü és jogállami büntetőeljárás megvalósításához. Véleményem szerint ez a kódex napjaink kívánalmainak megfelel, azonban a törvény a jogalkalmazó cselekvése nélkül csak üres betű. Talán elmondhatjuk, hogy a jogalkotó megtette a töle elvárhatót. Most a következő lépés a jogalkalmazó és az eljárás többi alanya kezében van. 